Kasa Ayten, B. ve Ercan, M. (2021). Ilkokul 4. sınıf Türkçe ders kitabında yer alan yazma etkinliklerinin incelenmesi. Ana Dili Eğitimi Dergisi, 9(3), 833-853.

Ana Dili Eğitimi Dergisi
Journal of Mother Tongue Education
www.anadiliegitimi.com
Geliş/Received: 01.03 .2021 Kabul/Accepted: 12.04 .2021
Araştırma Makalesi / Research Paper

\title{
ilkokul 4. Sınıf Türkçe Ders Kitabında Yer Alan Yazma Etkinliklerinin İncelenmesi
}

\author{
Başak KASA AYTEN* \\ Murat ERCAN**
}

Öz

Bu araştırmanın amacı, ilkokul 4. sınıf Türkçe ders kitabındaki yazma etkinliklerini incelemektir. Çalışmada nitel araştırma yaklaşımı benimsenmiş ve doküman incelemesi yöntemi kullanılmıştır. Ölçüt örnekleme yoluyla Millî Eğitim Bakanlığı (MEB) tarafından onaylı bir 4. sınıf Türkçe ders kitabı seçilmiş ve seçilen bu kitapta yer alan yazma etkinlikleri betimsel analiz tekniği ile analiz edilmiştir. Ders kitaplarındaki etkinliklerin analizi sonucu "Kazanımlar", "Süreç Temelli Yazma" ve "Metin Türüyle İlişkilendirilemeyen Etkinlikler" olmak üzere 3 tema ortaya çıkmıştır. Oluşturulan temalar ve alt temalar verilen örneklerle desteklenmiştir. Araştırmanın sonucunda ilkokul 4. sınıf Türkçe ders kitabındaki etkinliklerde bazı yazma kazanımlarına hiç değinilmediği, bütün aşamalar söz konusu olmasa da süreç temelli yazmaya ilişkin özellikle düzeltme ve yayınlama aşamalarına ilişkin etkinliklerin yer aldığı, bazı etkinliklerde metin türüne dair bir bilgilendirmenin yapılmadığı görülmüştür.

Anahtar Kelimeler: Türkçe ders kitabı, yazma etkinlikleri, doküman incelemesi

\section{A Review on the Writing Activities Included in the Turkish Course Textbook for the 4th Grade in Primary Schools}

\section{Abstract}

The aim of this research is to examine the writing activities in the primary school 4th grade Turkish course textbook. In the study, qualitative research approach was adopted and document analysis method was used. A 4th Grade Turkish Textbook approved by the Ministry of National Education (MEB) was selected through criterion sampling and the writing activities in this selected book were analyzed using descriptive analysis technique. As a result of the analysis of the activities in the textbooks, 3 themes emerged as "Outcomes", "Process Based Writing" and "Activities Not Associated with the Text Type". Themes and sub-themes are supported with the examples given. It is observed that some writing achievements were not mentioned at all in the activities in the 4th grade Turkish Course Book of the primary school, and since all stages are not in question, especially during the editing and publishing stages, information is not given to the text type at the places of various activities and in some activities.

Keywords: Turkish course textbook, writing activities, document analysis

\section{Giriş}

Dil, bireylerin sosyalleşmesini sağlayan, duygu ve düşüncelerini ortaya koyabilmesi için kullandığı bir iletişim aracıdır. Diline hâkim olan bireyler hem kendini rahat ifade edebilir hem de karşısındakinin ifadesini anlamlandırabilir. Dil hâkimiyeti ise dil becerilerinin doğru kazanılmasıyla ilişkilidir. Bu bağlamda dinleme, konuşma, okuma ve yazma becerilerinin kazanılması dilin doğru

\footnotetext{
* Dr. Öğr. Üyesi, İnönü Üniversitesi, Eğitim Fakültesi, Temel Eğitim Bölümü, Malatya, basak.kasa@inonu.edu.tr, ORCID: orcid.org/0000-0001-5926-3380

${ }^{* *}$ Yüksek Lisans Öğrencisi, İnönü Üniversitesi, Eğitim Bilimleri Enstitüsü, Temel Eğitim ABD, Malatya, muratercan0802@gmail.com, ORCID: orcid.org/0000-0001-9489-1200
} 
kullanılmasını, duygu ve düşüncelerin düzgün aktarılmasını, iletişimin daha etkili hale gelmesini sağlamaktadır.

Ilkokul, dil becerilerinin formel olarak kazandırıldığı ilk eğitim basamağıdır. Formel eğitime başlamadan önce birey bütün dil becerilerini aileden ve çevreden kazanmaya başlamaktadır. Ancak dinleme ve okuma gibi anlama becerilerinin yanı sıra konuşma ve yazma gibi anlatma, ifade etme becerilerinin kazandırılması ömür boyu süreceği gibi bu formel süreçte yoğunlukta olmaktadır. Bireyin ilkokuldan sonraki eğitim-öğretim yaşamında rahat edebilmesi için bu dil becerisi kazanımının ilkokulda çözüme kavuşturulması gerekmektedir (Özdemir, 2014). Bu bağlamda ilkokulda özellikle Türkçe derslerinde dil becerilerinin kazandırılmasına öncelik verilmektedir.

Bireylerin kendini yazılı bir şekilde ifade edebilmesini sağlayan yazma becerisi kazandırılması en zor olan becerilerdendir. Temizkan'a (2007, s. 136) göre yazma, "Bir konuyu seçme, sınırlandırma ve bir amaca bağlama işlemlerinden sonra konu ile ilgili bilgi toplama, toplanan bilgileri konunun bütünlüğü içinde planlama aşamalarından oluşan; planı yazıya dönüştürmek için anlatmak istenilene uygun kelimeler seçme, bunları doğru cümlelere dönüştürme, doğru cümlelerle sağlam paragraflar kurma, kelimeleri doğru yazma, noktalama işaretlerini yerinde kullanma, yazım kurallarına uyma, kâğıdın şekil yapısı ile ilgili kuralları uygulama, duyguları, düşünceleri plan çerçevesinde yazıya aktarma ve ortaya çıkan ürünü düzeltip değerlendirme süreçlerini içeren bir etkinlik şeklindedir." Kısacası yazma, zihinde yapılandırılmış bilgilerin belirli kurallara uygun birtakım sembollerle yazıya dökülmesi ve anlamlandırması işlemidir (Güneş, 2014; Karadağ, 2016). Türkçe Dersi Öğretim Programı'na göre; öğrencilerin duygu, düşünce, hayal, izlenim, tasarılarını dilin kurallarına uygun bir şekilde ifade etmelerini alışkanlık haline getirmeleri yazma becerisini geliştirmektedirler (MEB, 2015). Yazma eğitiminin amacı güzel yazı yazdırmanın haricinde bireylerin kendi duygu ve düşüncelerini düzenli bir şekilde, doğru ifadelerle, kendi yazı stilleriyle yazıya aktarabilmesini sağlamaktır. Yazma becerisinin eğitim verilmeden kazandırılması ise oldukça zordur.

Yazma eğitimi bireyin yazııı ifadesini kolaylaştırmalı, yazılı iletişimini kuvvetlendirmeli, konuyu ve olayları iyi analiz ederek duygu ve düşüncelerini doğru yönlendirebilmelidir. Yazma eğitiminde geleneksel yöntemlerle yürütülen yazma çalışmalarında yaratıc düşünmeye yönelik olmayan, alışııış, yeni ve özgün fikirlerin olmadığı konularda yazmak bir süre sonra öğrencilerin sıkılmasına ve isteksiz olmasına yol açmaktadır. Bu nedenle öğretmenin rehberlik etmediği yazma çalışmalarında öğrencinin kendine olan güveni azalmakta ve kendini ifade etmekte güçlük çektiği görülmektedir. Böyle olunca da yazma eylemi bir süre sonra sona ermektedir (Temizkan, 2014). Bu yaklaşım bilişsel süreçleri göz ardı ederken aynı zamanda metin üzerindeki çözümlemeleri yalnızca yapısal açıdan incelemesi ve süreci göz ardı etmesinden dolayı öğrencilerin yazma sürecindeki buluş, düzenleyiş ve anlayış basamaklarını ve bu basamaklardaki yaratıcılığını da görmezden gelir (Kavcar, 2009). Ürün temelli yaklaşımdan süreç temelli yaklaşıma geçiş, öğretmen rehberliğinde bireylerin hem biçim hem içerik olarak yazma becerilerinin gelişmesini sağlamaktadır. Bu yaklaşımda yazı, kişinin duygu, düşünce ve dilini keşfetmesi, yenilemesi, değiştirmesi olarak görülür. Bu nedenle öğretmen ve öğrenci ilişkisi usta-çırak ilişkisine benzer. Böylece öğretmen öğrencilerini daha iyi anlayabilir ve yol gösterebilir (Oral, 2012).

Süreç temelli yazma yaklaşımı, bireylerin yazılı bir metin oluştururken kullandıkları birbirine bağıı beş aşamayı içerir. Bu beş aşama hazırlık, taslak hazırlama, gözden geçirme, düzenleme ve yayınlamadır (Tompkins, 2002). Bu yaklaşımda hazırlık aşaması çok önemlidir ve ilk taslak oluşturma öncesinde yer alan bu aşamada yazma zamanının \%85'ini kapsar. Hazırlık aşamasında öğrenci konusunu, okuyucusunu ve yazı türünü seçer (Murray, 1972). Hazırlık aşamasında belirlenen konu, amaç, hedef kitle, toplanan bilgi ve fikirler taslak oluşturma aşamasında artık özgürce yazıya dökülür ve metnin akışı oluşturulur. Gözden geçirme aşamasında hem öğrenci yazııını gözden geçirir hem de akran ve öğretmen bakış açılarının ortaya konulmasını sağlar. Böylece birey düzeltme aşamasında yazının biçimsel düzenlemesini yaparak yayınlama aşamasıyla yazısını hedef kitleyle paylaşır (Kasa Ayten, 2018).

Bireyin öğretmen rehberliğinde belirli aşamaları göz önüne alarak yazması hem yazma becerisinin gelişmesini hem de yazmaya karşı olumlu tutum ve motivasyon geliştirmesini sağlayacaktır. Türkçe derslerinde yapılan yazma etkinlikleri sıradanlıktan ne kadar uzak olursa öğrenciler için o kadar dikkat çekici olacaktır. Bunun yanı sıra öğrencinin yazma becerisini süreç boyunca geliştirebileceğinin 
farkında olunması ve öğretmenin bu süreçte öğrenciyle birlikte olması, ona ışık tutması öğrencinin "Nasıl daha iyi yazabilirim?" sorusuna kendi içinde cevap bulmasını sağlayacaktır. Özellikle Türkçe ders kitaplarında yer alan etkinliklerin yazma becerisini geliştirici nitelikte olması öğretmenlerin bu süreçte büyük destekçisidir. Ders kitabındaki etkinliklerin niteliği yazma sürecini kolaylaştırır ve öğretmenin iş yükünü hafifletir. Aynı zamanda Çiçek ve Alcellat'a (2014) göre ders kitabındaki etkinlikler kazanımlar açısından pekiştireç niteliğindedir. Bu bağlamda etkinliklerin yazma kazanımlarıyla uyumu, farklı yazma kazanımlarını vurgulaması hem öğrencinin hem de öğretmenin yazma sürecine katkı sağlar. Öğrenci farklı yazma kazanımlarıyla kendinin yazma becerisini geliştirir ve öğrenmelerini pekiştirirken öğretmenler de ders kitabındaki etkinlikler doğrultusunda daha kolay dersi şekillendirebilir.

Etkinlik yaklaşımından hareketle Türkçe ders kitaplarında öğrencilere metinler sonunda farklı etkinlikler verilmekte ve bu etkinliklerle öğretim uygulanmaktadır. Ancak Türkçe ders kitabındaki etkinliklere bakıldığında bunların istenilen düzeyde ve nitelikte olmadığı, davranışçı yaklaşımın temel öğrenme aracı olan alıştırmalar şeklinde olduğu, sürekli olarak öğrencilere tekrar yapmaya yönelten nitelikte çalışmalar olduğu sonucuna varılmıştır (Çevik ve Güneş, 2017). Bu bağlamda Türkçe ders kitaplarındaki yazma etkinliklerini inceleyip yazma eğitimini sıradanlıktan çıkarıp geliştirmek önem taşımaktadır. Bu araştırmanın amacı, ilkokul 4. sınıf Türkçe ders kitabındaki yazma etkinliklerini incelemek ve kitaplarda yer alan etkinliklerin yazma becerisi doğrultusundaki durumunu ortaya koymaktır. Bu amaç doğrultusunda şu alt probleme cevap aranmıştır:

1. İlkokul 4. sınıf Türkçe ders kitabında yer alan etkinliklerin kazanımlara göre dağılımları nasıldır?

2. Illkokul 4. sınıf Türkçe ders kitabında yer alan etkinliklerin süreç temelli yazma boyutunda dağııımı nasıldır?

3. Illkokul 4. sınıf Türkçe ders kitabında yer alan etkinliklerin metin türlerine yönelik yönergeleri nasıldır?

\section{Araştırmanın Modeli}

\section{Yöntem}

Bu çalışmada nitel araştırma yaklaşımı benimsenmiş, nitel araştırma yaklaşımı içinde yer alan doküman incelemesi yöntemi kullanılmıştır. Wach $(2013$, s. 1) doküman analizini "yazılı belgelerin içeriğini titizlikle ve sistematik olarak analiz etmek için kullanılan bir araştırma yöntemi" olarak tanımlamıştır. Katılım kayıtları ve toplantı tutanakları, kılavuzlar, kitaplar ve broşürler, günlükler ve dergiler, etkinlik programları, mektuplar, haritalar ve çizelgeler, gazeteler, karalama defterleri ve fotoğraf albümleri vb. birçok belge doküman olarak değerlendirilebilir (Bowen, 2009). Doküman incelemesi yönteminde var olan belgeler üzerinde detaylı bir araştırma yapılmaktadır. Bu çalışmada da Türkçe ders kitabındaki etkinliklerin yazma becerisi yönünden incelenmesi amacıyla doküman incelemesi yöntemi kullanılmıştır.

\section{Örneklem}

Araştırmada amaçı̈ı örnekleme yöntemi türlerinden ölçüt örnekleme kullanılmıştır. Millî Eğitim Bakanlığı tarafından onaylı, geçerlik süresi devam eden, 2020-2021 eğitim öğretim yılında kullanılan ilkokul 4. sınıf Türkçe ders kitapları içerisinden bir kitap yansız olarak alınmıştır. Araştırmada Koza Yayınlarının 4. Sınıf Türkçe Ders Kitabı (Ataşçi, 2019) seçilmiştir. Bu bağlamda seçilen kitaptaki etkinlikler yazma etkinlikleri açısından incelenmiştir.

\section{Verilerin Toplanması ve Analizi}

Veriler doküman incelemesi yoluyla toplanmıştır. Doküman olarak ilkokul 4. Sınıf Türkçe ders kitabı seçilmiş ve bu kitapta yer alan yazma etkinlikleri incelenmiştir. Seçilen ilkokul 4 . sınıf Türkçe ders kitabında yer alan etkinliklerden elde edilen veriler betimsel analiz tekniğiyle anal iz edilmiştir. Betimsel analizde bilgiler belirlenmiş temalar üzerinden özetlenir, yorumlanır ve görüşlerinin ya da gözlemlerin daha etkili olması amacı için çoğunlukla doğrudan alıntı yapılır (Yıldırım ve Şimşek, 2018). Bu çalışmanın betimsel analiz tekniğiyle uygulanmasının amacı, araştırma konusuna yönelik literatürde yeterince bilginin olması ve ilkokul 4 . sınıf Türkçe ders kitabında yer alan yazma becerisi etkinliklerinin bu bilgiler 
açısından incelenmesidir. Bu bağlamda etkinlikler, Türkçe Dersi Öğretim Programı'nda yer alan 4. sınıf yazma kazanımlarına, süreç temelli yazma etkinliklerine ve metin türlerine yönelik incelenmiş ve veriler analiz edilmiştir.

\section{Geçerlik ve Güvenirlik}

Araştırmada her iki araştırmacı verileri analiz etmiş sonrasında elde edilen tema ve alt temalar karşılaştırılmıştır. Görüş ayrılığı olan temalar gözden geçirilip ortak bir nokta belirlenmiştir. Güvenilirlik için Miles ve Huberman'ın (1994) güvenirlik formülü kullanılmış [Güvenirlik=Görüş Birliği/(Görüş Birliği+Görüş Ayrılığı] ve sonuç olarak araştırmanın güvenirliği .94 olarak hesaplanmıştır. Güvenirlik sonucunun .70 üstü çıkması araştırmanın güvenilir olduğunu ortaya koymaktadır (Miles ve Huberman, 1994). Bu araştırmanın da güvenilir olduğu söylenebilir. Sonrasında bir alan uzmanının (Türkçe Eğitimi Ana Bilim Dalı öğretim üyesi) temalar üzerine görüşü ve onayı alınmıştır.

Araştırmanın aktarılabilirliğini için ayrıntılı betimleme yoluna gidilmiştir. Yıldırım ve Şimşek'e (2018, s. 282) göre "Ayrıntılı betimleme ham verinin ortaya çıkan kavram ve temalara göre yeniden düzenlenmiş bir biçimde okuyucuya yorum katmadan ve verinin doğasını mümkün olduğu ölçüde sadık kalınarak aktarıımasıdır.". Bu bağlamda bulgular bölümünde verilere ilişkin olarak örnekler, resimler ve yazılarla desteklenerek sunulmuştur.

\section{Araştırma ve Yayın Etiği}

Bu çalışmada "Yükseköğretim Kurumları Bilimsel Araştırma ve Yayın Etiği Yönergesi" kapsamında uyulması belirtilen tüm kurallara uyulmuştur. Yönergenin ikinci bölümü olan "Bilimsel Araştırma ve Yayın Etiğine Aykırı Eylemler" başlığı altında belirtilen eylemlerden hiçbiri gerçekleştirilmemiştir.

\section{Bulgular}

Verilerin analizinden elde edilen bulgular tema, alt tema, etkinlik numarası ve frekanslar şeklinde verilmiştir. Incelenen kitapta yer alan temalar Çocuk Dünyası, Milli Mücadele ve Atatürk, Erdemler, Milli Kültürümüz, Doğa ve Evren, Sanat, Birey ve Toplum, Bilim ve Teknolojidir. Etkinlik numarası verilirken kitaptaki tema adı, metin adı, etkinlik sırası verilerek tanımlanmışır. Örneğin Milli Kültürümüz/Bayrak/7 şeklindeki numaralandırma 4. tema Milli Kültürümüz'ün "Bayrak" metninin 7. etkinliğidir. Bazı etkinliklerde $a, b, c$ vb. şeklinde basamaklar bulunmaktadır. Kitapta yer alan tema sonlarındaki değerlendirme etkinlikleri kazanımlar boyutunda inceleme kapsamına alınmasa da süreç temelli yazma boyutundaki etkinliklere yer verilmiştir. Örneğin Çocuk Dünyası/Değerlendirme/8 etkinlik numarası 1. tema Çocuk Dünyası'nın değerlendirme bölümündeki 8. etkinliğidir. Bunun yanı sıra kazanımların numaraları verilmiştir. Bu numaralandırma Türkçe Dersi Öğretim Programı́nda yer aldığı şekliyle verilmiştir. Bu bağlamda kazanım numaralandırması örneği T.4.4.3 şeklinde ifade edilen kazanım için Türkçe Dersi 4. sınıf 4. dil becerisinin (Yazma) 3. kazanımı olarak verilebilir.

\section{Kazanımlar Temasına ilişskin Bulgular}

İlkokul 4. sınıf Türkçe ders kitabındaki yazma etkinlikleri "Kazanımlar, Süreç temelli yazma, Metin türüyle ilişkilendirilemeyen etkinlikler" olmak üzere üç tema üzerinde incelenmiştir. Tablo 1'de "Kazanımlar" temasına ilişkin bilgiler yer almaktadır.

Tablo 1.

Ilkokul 4. Sınıf Türkçe Ders kitabındaki Yazma Etkinliklerinde Yer Alan "Kazanımlar" Temasına ilişkin Bulgular

\begin{tabular}{llll}
\hline TEMA & ALT TEMALAR & ETKiNLiK NUMARASI & $\mathbf{f}$ \\
\hline $\bar{E}$ & T.4.4.1. Şiir yazar. & Çocuk Dünyası/Halay/7, & 6 \\
$\overline{\bar{N}}$ & & Milli Mücadele ve Atatürk/Başkomutan & \\
$\overline{\mathbb{N}}$ & & Mustafa Kemal/5c, & \\
$\overline{\widetilde{N}}$ & & Erdemler/Sevgi Çelengi/6,
\end{tabular}


T.4.4.2. Bir işin işlem basamaklarına ilişkin yönergeler yazar.

T.4.4.3. Hikâye edici metin yazar.

T.4.4.4. Bilgilendirici metin yazar.

T.4.4.5. Hayalî ögeler barındıran kısa metin yazar.

T.4.4.6. Görselleri ilişkilendirerek bir olayı anlatır.

T.4.4.7. Yazdıklarının içeriğine uygun başlık belirler.

T.4.4.8. Yazdıklarında yabancı dillerden alınmış, dilimize henüz yerleşmemiş kelimelerin Türkçelerini kullanır. T.4.4.9. Formları yönergelerine uygun doldurur.

T.4.4.10. Büyük harfleri ve noktalama işaretlerini uygun yerlerde kullanır.
Milli Kültürümüz/Bayrak/7,

Doğa ve Evren/Yağmur/9,

Sanat/Dört Büyük Şair/8

Birey ve Toplum/Ipek Kelebeği/7,

Bilim ve Teknoloji/Akıl Aydınlığında/8

Erdemler/Size Saygı Duyulmasını İstiyorsanız

4

Dürüst Olun/6,

Erdemler/Beş Kuruşun Ağırlığı/9,

Sanat/Çılgın Böcekler Korosu/9,

Bilim ve Teknoloji/Internet/7

Milli Mücadele ve Atatürk/Atatürk/6b,

Milli Kültürümüz/Genç Osman Destanı/6,

Doğa ve Evren/Yeşilyurt/ $5 c ̧$

Doğa ve Evren/Yeşilyurt/6,

Bilim ve Teknoloji/Öğrenme ve Marie Curie/7,

Bilim ve Teknoloji/Akıl Aydınlığında/8

Erdemler/Size Saygı Duyulmasını İstiyorsanız

Dürüst Olun/6,

Erdemler/Beş Kuruşun Ağırlığı/9,

Sanat/Çılgın Böcekler Korosu/9

Çocuk Dünyası/Arkadaşlık/10

Çocuk Dünyası/Kuş Çocuk/8,

Çocuk Dünyası/Halay/7,

Milli Kültürümüz/Hepsi Haklı/7,

Milli Kültürümüz/Bayrak/7,

Doğa ve Evren/Yeşilyurt/6,

Doğa ve Evren/Ateş Böceği/ 5 ,

Sanat/Çılgın Böcekler Korosu/9,

Birey ve Toplum/Ah Heidi Neredesin?/7,

Bilim ve Teknoloji/Beyin Ne iş Yapar?/7

Sanat/Dört Büyük Şair/6

Sanat/Fotoğrafın İcadı/5,

Bilim ve Teknoloji/Öğrenme ve Marie Curie/7

Çocuk Dünyası/Kuş Çocuk/8,

Çocuk Dünyası/Halay/7,

Milli Mücadele ve Atatürk/Müstecip Onbaşı/8,

Erdemler/Leylek ve Tilki/6b,

Erdemler/Size Saygı Duyulmasını İstiyorsanız

Dürüst Olun/6,

Erdemler/Beş Kuruşun Ağırlı̆̆ı/9,

Milli Kültürümüz/Hepsi Haklı/5,

Milli Kültürümüz/Hepsi Haklı/7, 
T.4.4.11. Yazdıklarını düzenler.

T.4.4.12. Yazdıklarını paylaşır.
Milli Kültürümüz/Tarihi Eserleri ve Mutfağıyla

Ünlü Kentimiz Hatay/6,

Milli Kültürümüz/Bayrak/7,

Milli Kültürümüz/Genç Osman Destanı/6,

Doğa ve Evren/Yeşilyurt/6,

Doğa ve Evren/Küçük müyüz, Büyük mü?/8,

Doğa ve Evren/Ateş Böceği/ 5 ,

Sanat/Çılgın Böcekler Korosu/9,

Sanat/Sinema/5,

Sanat/Sinema/7,

Birey ve Toplum/Eskisiyle Para Babası/7,

Birey ve Toplum/ipek Kelebeği/7,

Bilim ve Teknoloji/Internet/7

Çocuk Dünyası/Kuş Çocuk/8,

Çocuk Dünyası/Halay/7,

Milli Mücadele ve Atatürk/Müstecip Onbaşı/8,

Erdemler/Leylek ve Tilki/6b,

Erdemler/Size Saygı Duyulmasını İstiyorsanız

Dürüst Olun/6,

Erdemler/Beş Kuruşun Ağırlığı/9,

Milli Kültürümüz/Hepsi Haklı/7,

Milli Kültürümüz/Tarihi Eserleri ve Mutfağıyla

Ünlü Kentimiz Hatay/6,

Milli Kültürümüz/Bayrak/7,

Milli Kültürümüz/Genç Osman Destanı/6,

Doğa ve Evren/Yeşilyurt/6,

Doğa ve Evren/Küçük müyüz, Büyük mü?/8,

Doğa ve Evren/Ateş Böceği/5,

Sanat/Çılgın Böcekler Korosu/9,

Sanat/Sinema/7,

Birey ve Toplum/Eskisiyle Para Babası/7,

Birey ve Toplum/ipek Kelebeği/7,

Bilim ve Teknoloji/Internet/7

Milli Mücadele ve Atatürk/Müstecip Onbaşı/8,

Erdemler/Leylek ve Tilki/6b,

Erdemler/Size Saygı Duyulmasını İstiyorsanız

Dürüst Olun/6,

Erdemler/Sevgi Çelengi/6,

Erdemler/Beş Kuruşun Ağırlığı/9,

Milli Kültürümüz/Hepsi Haklı/7,

Milli Kültürümüz/Tarihi Eserleri ve Mutfağıyla

Ünlü Kentimiz Hatay/6,

Milli Kültürümüz/Bayrak/7,

Doğa ve Evren/Yeşilyurt/5ç,

Doğa ve Evren/Yeşilyurt/6,

Doğa ve Evren/Küçük müyüz, Büyük mü?/8,

Sanat/Çılgın Böcekler Korosu/9,

Sanat/Sinema/7,

Birey ve Toplum/Sözcükler/6,

Birey ve Toplum/Ipek Kelebeği/7, 
T.4.4.13. Yazılarında eş sesli kelimeleri anlamlarına uygun kullanır.

T.4.4.14. Yazdıklarını zenginleştirmek için çizim, grafik ve görseller kullanır.

T.4.4.15. Imza atar.

T.4.4.16. Kısaltmaları ve kısaltmalara gelen ekleri doğru yazar.

T.4.4.17. Sayıları doğru yazar.

T.4.4.18. Yazılarında bağlaçları kuralına uygun kullanır.

T.4.4.19. Yazılarında kelimeleri gerçek, mecaz ve terim anlamları ile kullanır.

T.4.4.20. Harflerin yapısal özelliklerine uygun metin yazar.

T.4.4.21. Yazma stratejilerini uygular.

T.4.4.22. Pekiştirmeli sözcükleri doğru yazar.

\section{Bilim ve Teknoloji/Internet/7}

Sanat/Dört Büyük Şair/8

Çocuk Dünyası/Halay/7,

Erdemler/Sevgi Çelengi/6,

Doğa ve Evren/Ateş Böceği/5,

Bilim ve Teknoloji/Beyin Ne iş Yapar?/7

Milli Mücadele ve Atatürk/Atatürk/5,

Birey ve Toplum/Sözcükler/6

Sanat/Dört Büyük Şair/6

Erdemler/Size Saygı Duyulmasını İstiyorsanız Dürüst Olun/6

Tablo 1'de görüldüğğ gibi ilkokul 4. sınıf Türkçe ders kitabındaki yazma etkinlikleri "Kazanımlar" teması altında Türkçe Dersi Öğretim Programı 4. sınıf kazanımlarında yer alan 22 kazanım göz önüne alınarak alt temalar oluşturulmuştur. Tabloda görüldüğü üzere ders kitabında en fazla 10. kazanım $(f=20)$ vurgulanmıştır. Bu sırayı 11. kazanım $(f=18), 12$. kazanım ( $f=16), 7$. kazanım $(f=9), 1$ ve 4. kazanımlar ( $f=6)$, 3 ve 14. kazanımlar $(f=4)$, 5. kazanım $(f=3), 2,9$ ve 15. kazanımlar $(f=2), 6,8,13,16$, 18 ve 19. kazanımlar $(\mathrm{f}=1)$ takip etmiştir. "T.4.4.10. Büyük harfleri ve noktalama işaretlerini uygun yerlerde kullanır." adlı 10. kazanıma ilişkin şu şekilde bir örnek verilebilir:

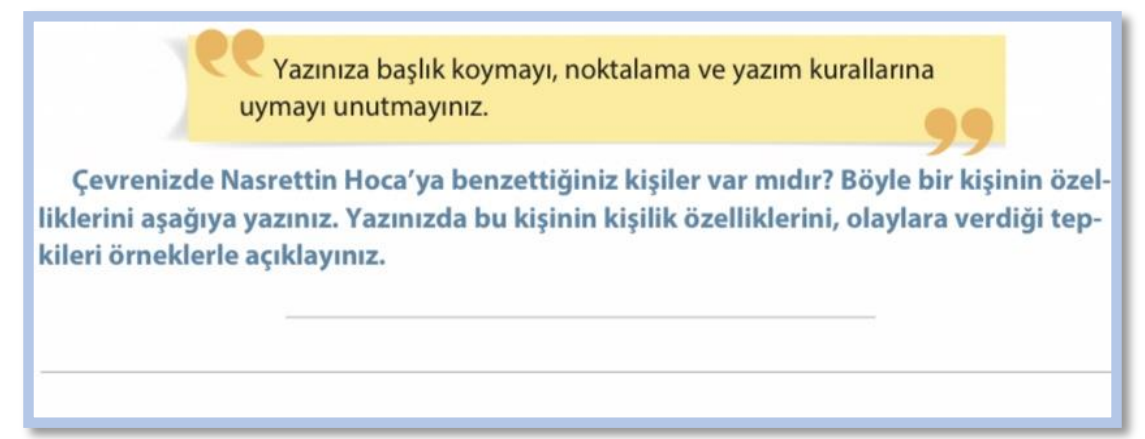

Resim 1. "Milli Kültürümüz/Hepsi Haklı/7. Etkinlik” Örneği (Ataşçi, 2019, s. 113) 
Örnekte görüldüğü gibi Milli Kültürümüz temasının "Hepsi Haklı” metninin 7. Etkinliğinde öğrencilere çevrelerinde Nasrettin Hoca'ya benzeyen bir kişinin özelliklerini ve olaylara verdiği tepkileri yazmaları istenirken yazım kurallarına ve noktalama işaretlerinin doğru kullanımına dikkat etmeleri gerektiği vurgulanmıştır. 10. kazanımın yer aldığı etkinlikler incelendiğinde yazma süreci sonunda noktalama işaretlerini kontrol etme yönünde olduğu görülmektedir. "T.4.4.7. Yazdıklarının içeriğine uygun başık belirler." şeklindeki 7. kazanıma ilişkin de bu etkinlikte örnek söz konusudur. Etkinlikte noktalama işaretleriyle beraber yazım kuralları da dikkat çekmektedir. Bu bağlamda "T.4.4.11. Yazdıklarını düzenler." şeklindeki 12. kazanım da 10. kazanımla beraber vurgulanmıştır. Bu örnek dışında 12. kazanıma ilişkin ise şöyle bir örnek de verilebilir:

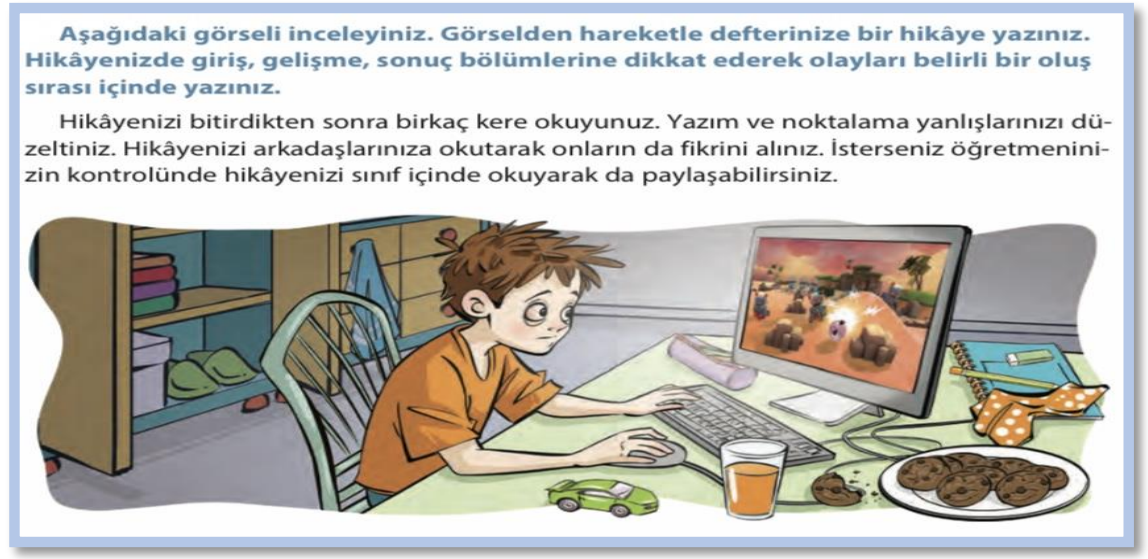

Resim 2. "Bilim ve Teknoloji/Internet/7. Etkinlik" Örneği (Ataşçi, 2019, s. 255)

Resim 2 örneğinde görüldüğü üzere Bilim ve Teknoloji temasının "Internet" metninin 7. etkinliğinde 12. kazanım, görselden yola çıkarak bir hikâye yazmaları ve metin oluşturulduktan sonra ise yazım ve noktalama yanlışları düzeltilerek öğretmenle ve sınıftaki diğer öğrencilerle paylaşılması şeklinde yer almıştır. Öğrencilerin metin oluştururken yazım ve noktalama işaretlerine dikkat etmesi gerektiğine ilişkin kitapta yeterince etkinliğin olduğu söylenebilir.

Metin türü olarak Türkçe Dersi Öğretim Programında bilgilendirici metin, hikâye edici metin, şiir şeklinde 3 metin türü de vurgulanmakta ve ders kitaplarında da bu türden metinlerin yer aldığı görülmektedir. 1. Kazanım "T.4.4.1. Şiir yazar.", 3. Kazanım "T.4.4.3. Hikâye edici metin yazar." ve "T.4.4.4. Bilgilendirici metin yazar." şeklindeki kazanımlar da bu metin türlerine vurgu yapmaktadır.

Çocuk Dünyası teması "Rafadan Tayfa ile Sokak Oyunları" metninin 7. etkinliğinde "Kardeşlik, sevgi, paylaşma" kavramlarından hareketle kısa bir şiir yazınız. Şiirinize başlık koymayı unutmayınız. Şiirinizi bitirdikten sonra tekrar okuyarak yazım ve noktalama yanlışları varsa bunları düzeltiniz." şeklindeki yönlendirmede şiir yazma ile ilgili öğrencilere yazma etkinliği verilmektedir. Bunun yanı sıra Türkçe Dersi Öğretim Programı'nda sınıf düzeyine göre metin türlerinin dağılımında (MEB, 2019, s. 19) şiir türünün altında tekerlemelerin 1-4. sınıfta kullanılabileceği belirtilmiştir. Tekerlemeye ilişkin metin türü öğrencilere metin olarak verilmese de Milli Mücadele ve Atatürk teması "Başkomutan Mustafa Kemal" metni $5 c$ etkinliğinde "Noktalama işaretlerinden bazılarıyla ilgili iki tekerleme yazınız." yönergesiyle öğrencilerden tekerleme yazmaları istenmiştir. Ancak tekerlemenin özelliğine ya da tekerleme yazımındaki kurallara ilişkin bir bilgi verilmemiştir. 


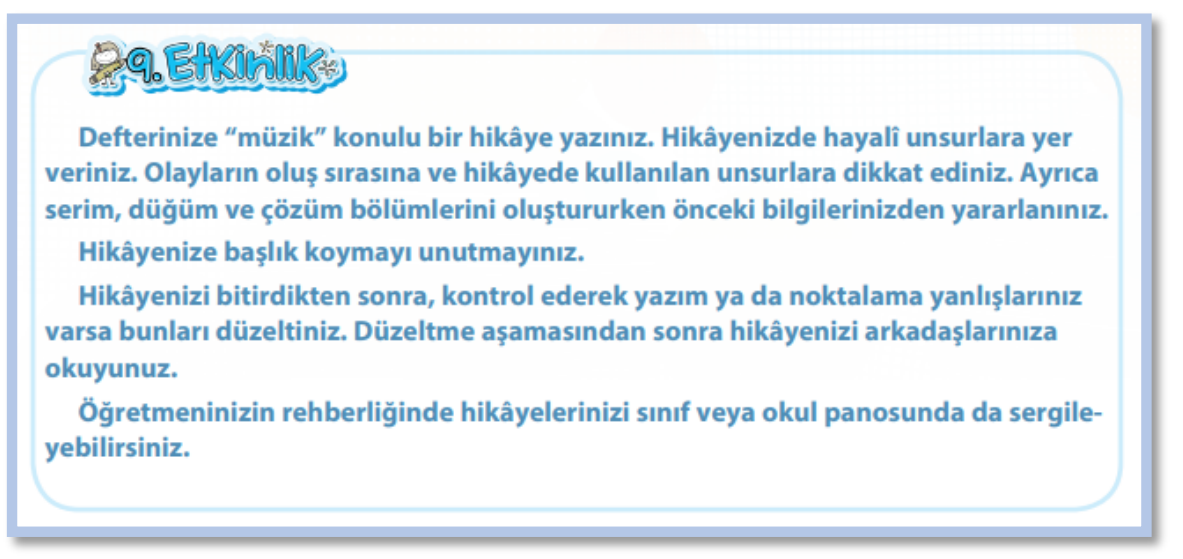

Resim 3. "Sanat/Çılgın Böcekler Korosu/9. Etkinlik” Örneği (Ataşçi, 2019, s. 179)

"T.4.4.3. Hikâye edici metin yazar." 3. kazanımına ilişkin Resim 3'teki Sanat teması "Çılgın Böcekler Korosu" 9. etkinliğinde görüldüğg̈ gibi öğrencilere hikâye yazmalarına ilişkin bir yönerge verilmektedir. Hikâye yazmaya ilişkin yönergede aynı zamanda "T.4.4.5. Hayalî ögeler barındıran kısa metin yazar." şeklindeki 5. kazanımına, "T.4.4.7. Yazdıklarının içeriğine uygun başlık belirler." şeklindeki 7. kazanımına, "T.4.4.12. Yazdıklarını paylaşır." 12. kazanımına da yer verildiği görülmektedir. Yazma etkinlikleri sırasında özellikle birçok kazanımın beraber vurgulandığı dikkat çekmektedir. Bir yazma etkinliğinde tür, yazım, kurallar vb. birçok işlem bir arada olduğu için kazanımların da iç içe olması sürece uygundur.

"T.4.4.4. Bilgilendirici metin yazar." bilgilendirici metin türüne ilişkin kazanımda ise şöyle bir örnek verilebilir:

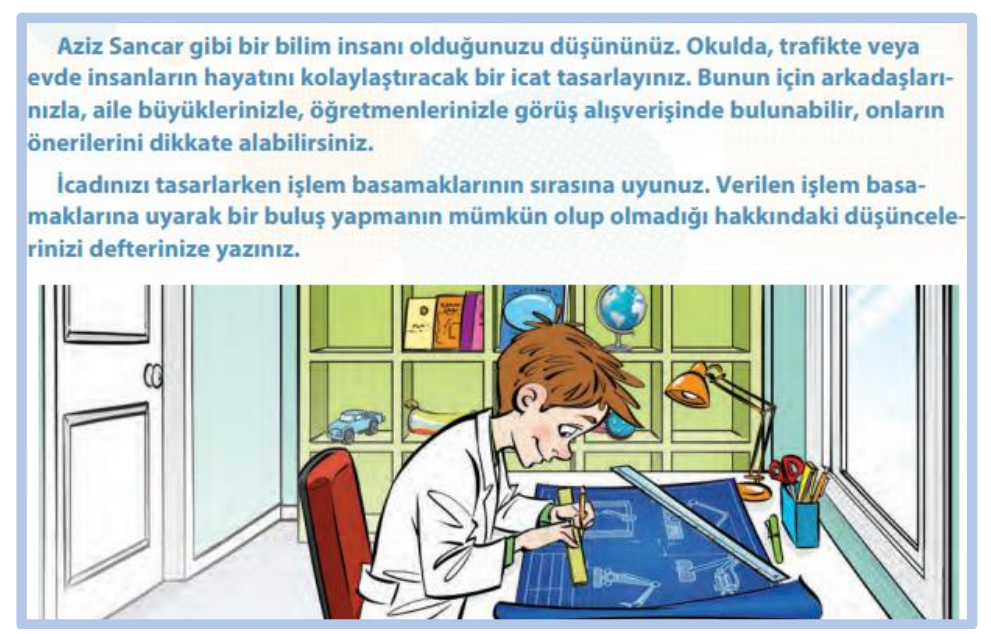

Resim 4. "Bilim ve Teknoloji/Akıl Aydınlığında/8. Etkinlik" Örneği (Ataşçi, 2019, s. 251)

Resim 4'te Bilim ve Teknoloji teması "Akıl Aydınlığında" metninin 8. etkinliğinde görüldüğü gibi öğrencilerin yaptığı bir icada yönelik duygu ve düşüncelerin yazılması istenmiştir. Türkçe Dersi Öğretim Programı'nda T.4.4.4. kazanıma ilişkin “a) Yazdıklarında duygu ve düşüncelerini aktarmaları için teşvik edilir. b) Verilen ya da kendi belirledikleri bir konu hakkında araştırma yapmaları sağlanır." şeklinde açıklamalar verilmektedir. Bununla ilişkilendirildiğinde etkinlikte öğrencilerin bilgilendirici metin türüne yönlendirildiği de düşünülebilir. 


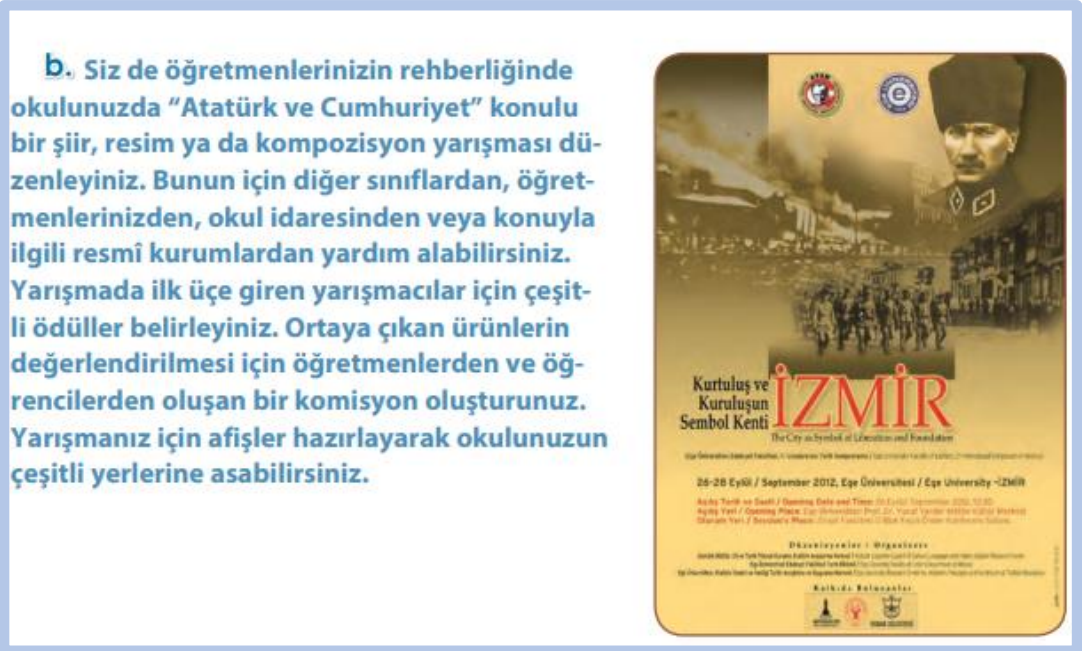

Resim 5. “Milli Mücadele ve Atatürk/Atatürk/6b. Etkinlik" Örneği (Ataşçi, 2019, s. 71)

Türkçe Dersi Öğretim Programı'nda bilgilendirici metin türü içerisinde "Efemera ve Broşür (liste, diyagram, tablo, grafik, kroki, harita, afiş vb. karma içerikli metinler)" şeklindeki açıklamada afi̧̧ de yer almaktadır (MEB, 2019, 17). Bu bağlamda afiş oluşturmaya ilişkin olarak Resim 5'teki Milli Mücadele ve Atatürk teması "Atatürk" metnindeki $6 b$ etkinliği örnek verilebilir. Resim 5'te görüldüğü gibi "Afiş hazırlayarak okulunuzun çeşitli yerlerine asabilirsiniz." yönergesiyle öğrencilerin afiş hazırlamalarına yönelik bir etkinlik verilmiştir. Ancak etkinlikte afiş hazırlama sürecine ilişkin bir bilgiye rastlanmamıştır.

Türkçe ders kitabında "T.4.4.14. Yazdıklarını zenginleştirmek için çizim, grafik ve görseller kullanır." şeklindeki 14. kazanıma ilişkin de şöyle bir örnek verilebilir.

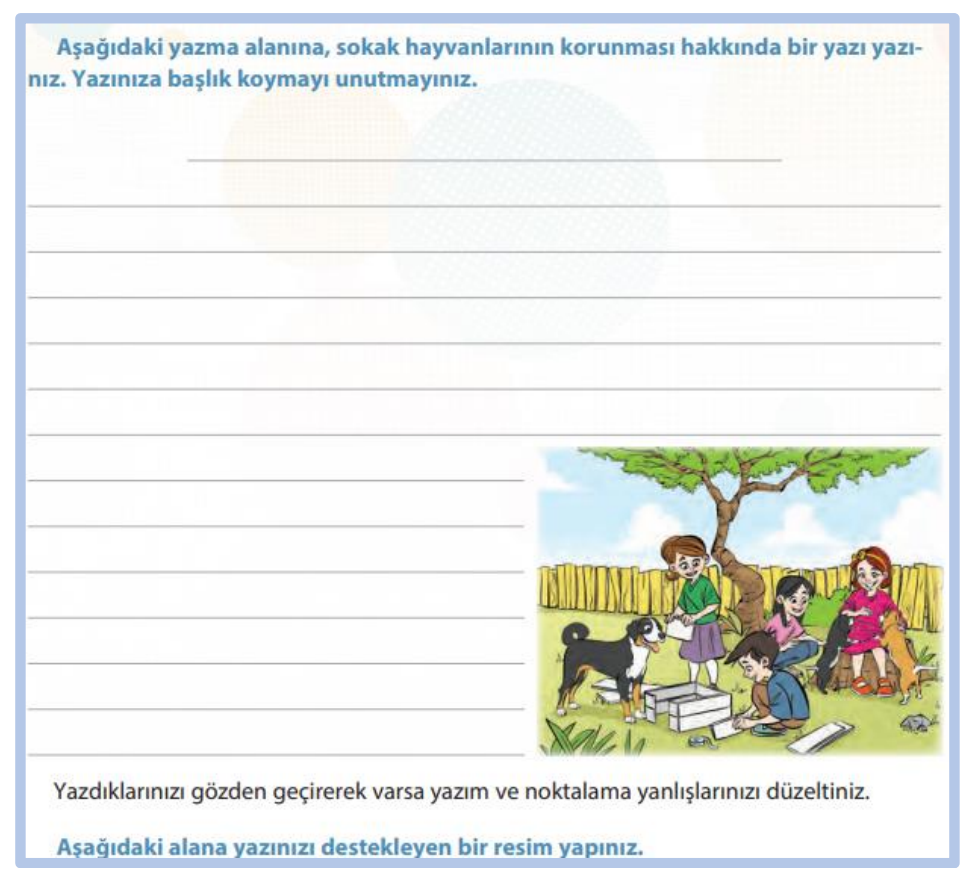

Resim 6. “Doğa ve Evren/Ateş Böceği/5. Etkinlik” Örneği (Ataşçi, 2019, s. 165)

Resim 6'da yer alan Doğa ve Evren tema "Ateş Böceği" metninin 5. etkinliği incelendiğinde öğrencilerin bir konu hakkında yazı yazmaları, yazılarına uygun başlık koymaları, yazım ve noktalama yanlışlarını gözden geçirmeleri ve yazılarını destekleyici resimler yapmaları istenmiştir. Bu etkinlik örneğinde de birden çok kazanımla öğrencilerin yazmaya yönelik becerilerinin geliştirilmesi hedeflenmiştir. 
Bu örnekler haricinde incelenen Türkçe dersi kitabında "T.4.4.17. Sayıları doğru yazar.", "T.4.4.20. Harflerin yapısal özelliklerine uygun metin yazar.", "T.4.4.21. Yazma stratejilerini uygular." ve "T.4.4.22. Pekiştirmeli sözcükleri doğru yazar." kazanımlarına ilişkin bir örneğe rastlanmamıştır. Etkinliklerde kazanımların olmaması öğretmenlerin bu kazanımları öğrencilere kazandırmayacağı anlamına gelmemektedir. Ancak ders kitabındaki etkinliklerin incelenmesi hangi kazanımlarda öğretmenlere daha çok iş düşeceğini, öğretmenlerin hangi konulara ilişkin etkinlikler tasarlayacağını gösterebilir.

\section{Süreç Temelli Yazma Temasına iliş̧in Bulgular}

Süreç temelli yazmada hazırlık, taslak oluşturma, gözden geçirme, düzeltme ve yayınlama aşamaları söz konusudur. Tablo 2 incelendiğinde süreç temelli yazma aşamalarının hepsine etkinliklerde yer verilmemiş ve Süreç Temelli Yazma Etkinlikleri teması altında "Hazırlık", "Taslak Oluşturma", "Düzeltme", "Yayınlama" ve "Aşamalara dikkat çekme" olarak 5 alt tema oluşturulmuştur.

Tablo 2.

Ilkokul 4. Sınıf Türkçe Ders kitabındaki Yazma Etkinliklerinde Yer Alan "Süreç Temelli Yazma" Temasına ilişkin Bulgular

\begin{tabular}{llll}
\hline TEMA & ALT TEMALAR & ETKinLik NUMARASI & $f$ \\
\hline Hazırlık aşaması & Çocuk Dünyası/Kuş Çocuk/8 & 1 \\
& Taslak Oluşturma & $\begin{array}{l}\text { Doğa ve Evren/Küçük müyüz, Büyük mü?/8, } \\
\text { Sanat/Dört Büyük Şair/8 } \\
\end{array}$ & Bilim ve Teknoloji/Beyin Ne iş Yapar?/7
\end{tabular}

Düzeltme aşaması

Çocuk Dünyası/Kuş Çocuk/8,

Çocuk Dünyası/Halay/7,

Milli Mücadele ve Atatürk/Müstecip Onbaşı/8,

Erdemler/Leylek ve Tilki/6b,

Erdemler/Size Saygı Duyulmasını İstiyorsanız Dürüst

Olun/6,

Erdemler/Beş Kuruşun Ağırlığı/9,

Milli Kültürümüz/Hepsi Haklı/7,

Milli Kültürümüz/Tarihi Eserleri ve Mutfağıyla Ünlü

Kentimiz Hatay/6,

Milli Kültürümüz/Bayrak/7,

Milli Kültürümüz/Genç Osman Destanı/6,

Doğa ve Evren/Yeşilyurt/6,

Doğa ve Evren/Küçük müyüz, Büyük mü?/8,

Doğa ve Evren/Ateş Böceği/ 5 ,

Sanat/Çılgın Böcekler Korosu/9,

Sanat/Sinema/7,

Birey ve Toplum/Eskisiyle Para Babası/7,

Birey ve Toplum/Ipek Kelebeği/7,

Bilim ve Teknoloji/Internet/7

Yayınlama aşaması

Milli Mücadele ve Atatürk/Müstecip Onbaşı/8,

Erdemler/Leylek ve Tilki/6b,

Erdemler/Size Saygı Duyulmasını İstiyorsanız Dürüst

Olun/6,

Erdemler/Sevgi Çelengi/6,

Erdemler/Beş Kuruşun Ağırlığı/9, 
Milli Kültürümüz/Hepsi Hakı//7,

Milli Kültürümüz/Tarihi Eserleri ve Mutfağıyla Ünlü

Kentimiz Hatay/6,

Milli Kültürümüz/Bayrak/7,

Doğa ve Evren/Yeşilyurt/6,

Doğa ve Evren/Küçük müyüz, Büyük mü?/8,

Sanat/Çılgın Böcekler Korosu/9,

Sanat/Sinema/7,

Birey ve Toplum/Sözcükler/6,

Birey ve Toplum/Ipek Kelebeği/7,

Bilim ve Teknoloji/Internet/7

Aşamalara dikkat çekme Çocuk Dünyası/Değerlendirme/8,

Türkçe ders kitabındaki etkinliklere bakıldığında süreç temelli yazma aşamalarından detaylı bir şekilde bahsedilmediği görülmektedir. Süreç Temelli Yazma temasındaki "Hazırlık Aşaması" alt temasında yer alan etkinlikte $(f=1)$ şöyle bir örnek verilebilir:

Yazınıza başlamadan önce okuyucuya nasıl bir mesaj vereceğinizi düşününüz. Bu mesajın yazacağınız metnin ana fikri olduğunu unutmayınız.

Yazıların giriş, gelişme ve sonuç bölümleri vardır. Giriş bölümünde ele almak istediğiniz konu hakkında okuyucuda merak uyandıracak bir giriş yapmalısınız. Gelişme bölümünde okuyucuya hangi bilgileri vermek istiyorsanız bunları örneklerle açıklamalısınız. Sonuç bölümünde ise düşüncelerinizi bir sonuca bağlamanız gerekir. Metinlerin giriş ve sonuç bölümleri kısa, gelişme bölümü ise daha uzundur. Yazınızda giriş, gelișme ve sonuç bölümlerinde hangi bilgilere ve düșüncelere yer vermek istiyorsanız bunları öncelikle tasarlayınız.

Resim 7. “Çocuk Dünyası/Kuş Çocuk/8. Etkinlik Numarası” Örneği (Ataşçi, 2019, s. 20)

Resim 7'de yer alan Çocuk Dünyası teması "Kuş Çocuk" metni 8. etkinliğine göre öğrencilerden sevdikleri özelliklerini kaybetmemek için yapmaları gerekenler hakkında bir yazı yazmaları istenmektedir. Hazırlık aşamasında yazılacak metnin konusu, amacı ve türü belirlendikten sonra konuyu sınırlandırmak adına konunun hangi yönünün ele alınacağı belirlenmelidir. Bu aşamada yazmaya başlamadan önce öğrenciden yazacağı metne ilişkin bir mesaj yani bir ana fikri belirlemesi istenmiştir. Ancak hazırlık aşaması sadece konu belirleme aşaması değildir. Birey yazacağı türe, hedef kitlesine, anlatım tarzı vb. yazının unsurlarına bu aşamada karar vermektedir. Bu bağlamda kitapta yer alan etkinlikte hazırlık aşamasına dair eksik olduğu söylenebilir. Bu etkinlikler yazma sürecinde usta çırak ilişkisinde olması gereken öğretmen öğrenci için sadece bir ipucu olabilir. Öğretmen bu süreçte öğrencilerine daha fazla rehberlik sağlamalıdır.

"Taslak Oluşturma" alt temasında $(f=3)$ yer alan etkinlikler ise öğrencinin yazacağı konuya ilişkin zihninde tasarlaması yönündedir. Doğa ve Evren teması “Küçük müyüz Büyük mü?” metninin 8. etkinliği "Yazma sürecine öncelikle yazmak istediklerinizi zihninizde tasarlayarak başlayınız. Gerekirse bunları maddeler hâlinde not alınız. Ardından konuyu ele alırken giriş, gelişme ve sonuç bölümlerini nasıl ele alacağınızı belirleyiniz", Sanat teması "Dört Büyük Şair" metni 8. etkinliği "Şiirinizi yazmadan önce yazmak istediklerinizi zihninizde tasarlayınız" örneklerinde de görüldüğü gibi bir taslak oluşturma sürecinden bahsedilmektedir. Ancak kitaptaki taslak oluşturma süreçleri zihinde tasarlama şeklinde kısaca geçilmiştir. Tam aksine taslak oluşturma süreci öğrencinin belirlediği konuyu nasıl ele alacağına 
ilişkin planlamasını, hazırlık aşamasındaki konu, kitle, tür seçiminin tasarıya dönüşmesini içermelidir. Taslak oluşturma aşaması kitaptaki etkinliklerde tam uygulanmadığı için gözden geçirme aşamasına ilişkin kitaptaki yazma etkinliklerde bir yönergenin olmadığı görülmektedir. Taslak oluşturma sürecinde ortaya çıkan yapının şekillendiğinin görüldüğü gözden geçirme aşamasında öğrencilerin yazıları içerik açısından öğretmen tarafından kontrol edilmeli, metnin planlanan içeriğe uygun olması sağlanmalıdır. Bu bağlamda ders kitabındaki etkinliklerin, metnin içeriğinin düzenlenmesi açısından eksik olduğu görülebilir.

Süreç Temelli Yazma teması altındaki "Düzeltme Aşaması" alt temasındaki etkinlikler ( $f=18$ ) incelendiğinde şu şekilde örnekler verilebilir:

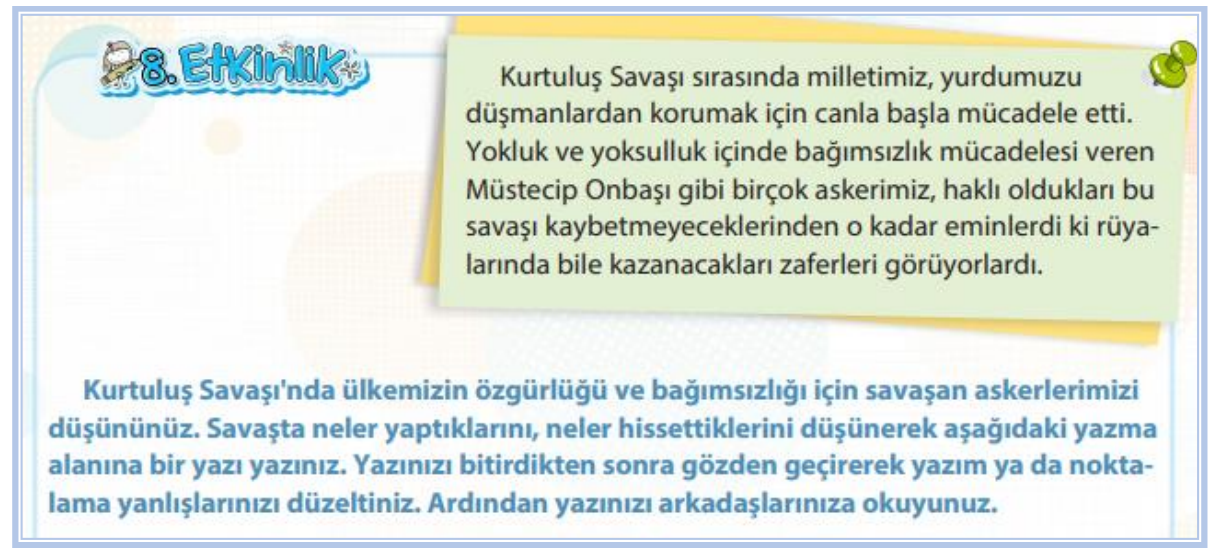

Resim 8. “Milli Mücadele ve Atatürk/Müstecip Onbaşı/8. Etkinlik” Örneği (Ataşçi, 2019, s. 53)

Resim 8'de Milli Mücadele ve Atatürk teması "Müstecip Onbaşı” metni 8. etkinliğinde öğrencilerden bir yazı yazmaları istenmektedir. Kitapta yer alan bu etkinlikte, öğrencilerin yazıyı bitirdikten sonra metni gözden geçirerek yazım ya da noktalama yanlışlarını düzeltmelerine dikkat çekilmiştir.

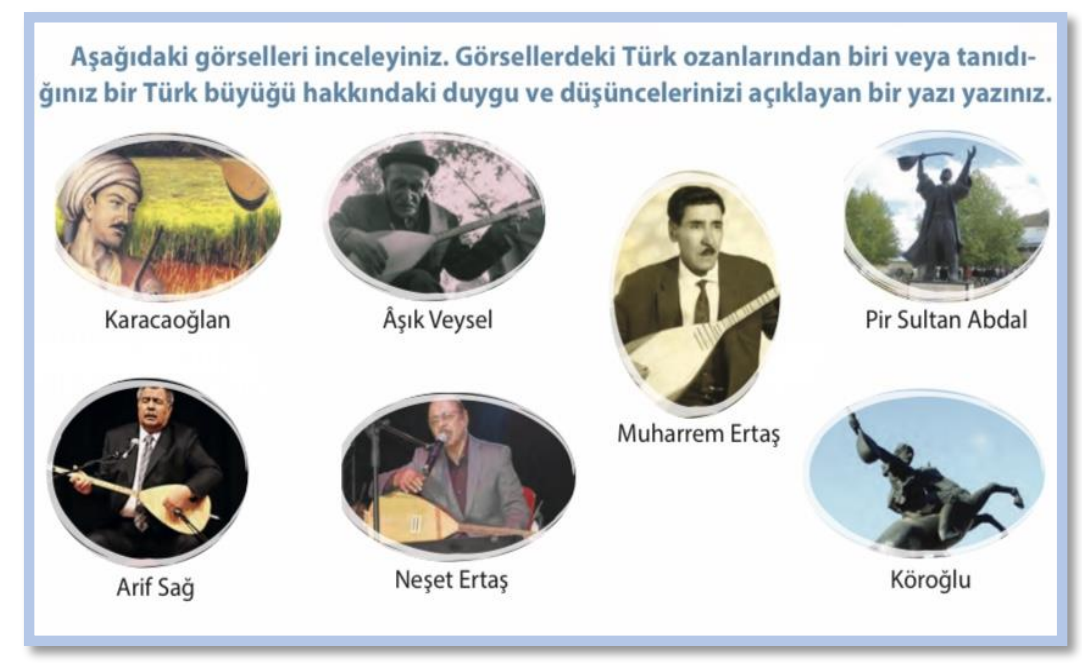

Resim 9. “Milli Kültürümüz/Genç Osman Destanı/6. Etkinlik” Örneği (Ataşçi, 2019, s. 128)

Resim 9'daki Milli Kültürümüz teması "Genç Osman Destanı" metni 6. etkinlikte Türk ozanlarından çeşitli örnekler verilerek, öğrencilerden aralarından birini veya farklı bir Türk büyüğü hakkında duygu ve düşüncelerini yazmaları istenmiştir. Yazıyı bitirdikten sonra gözden geçirerek yazım ya da noktalama yanlışları varsa bunları düzeltmeleri istenmektedir. Bu aşamada anlatılan olayların ve ifade edilen düşüncelerin tutarlı bir biçimde yazılması, paragraflar arasında mantıklı bir bütünlük olması, imla ve noktalamaya dikkat edilmesi gerekmektedir. Ayrıca düzeltme aşamasında öğrenci 
yazısının okunaklııı durumu da önemli bir yer edinmektedir. Metnin bitiminde okunaklı olmayan kısımlar gerekli şekilde düzeltilmelidir.

Düzeltme aşamasında bir metin, birden fazla kez gözden geçirilerek öğrencinin kendi hatalarını görerek düzeltmesi sağlanmalıdır. Ancak önemli olan biçimsel düzeltmeden ziyade öğrencinin içerik olarak yazılarını kontrol etmesidir. Düzeltme aşamasına kadar taslak oluşturma ve gözden geçirme aşamalarıyla öğretmen öğrencinin yazılarının içeriğini düzenlemektedir. Bu bağlamda öğretmenler, öğrencilerin yazılarının içerik düzenlemesini göz ardı etmemelidir. İncelenen Türkçe ders kitabına bakıldığında bu süreçlerin göz ardı edildiği görünmektedir. Süreç temelli yazmada öğrencilerin içerik anlamında yazılarına şekil verilmesi, öğrencilerin akranlarıyla ve öğretmenleriyle beraber yazılarını gözden geçirmesi ve düzeltmesi isteniyorsa özellikle bu aşamaların dikkate alınması gerekmektedir. Bu bağlamda taslak oluşturma ve gözden geçirme aşamalarına ilişkin kitaplarda etkinlik yönergeleri verilebilir.

Süreç Temelli Yazma temasındaki "Yayınlama Aşaması" alt temasında yer alan etkinliklere ( $f=15)$ şöyle örnekler verilebilir:

Türk bayrağı konulu kısa bir şiir yazınız. Şiirinize başlık koymayı unutmayınız. Şiirinizi bitirdikten sonra gözden geçirerek varsa yazım ve noktalama yanlışlarınızı düzeltiniz. Şiirinizi arkadaşlarınıza okuyunuz.

Resim 10. "Milli Kültür/Bayrak/7. Etkinlik" Örneği (Ataşçi, 2019, s. 124)

Resim 10'da Milli Kültürümüz teması "Bayrak" metni 7. etkinliğinde görüldüğü gibi öğrencilerden Türk bayrağı konulu bir şiir yazmaları istenmektedir. Şiir yazıldıktan sonra gerekli düzeltmeler yapılarak ortaya çıkan yazılı metnin paylaşılması belirtilmektedir. Yayınlama aşamasında ortaya konulan metnin, hedef kitlenin bulunduğu ortamda okunarak ya da panoda sergilenerek paylaşılması öğrencinin yazmaya karşı isteğini arttırabilir. Ancak burada dikkat edilmesi gereken nokta süreç içinde öğrencinin kendi yazılarını oluştururken öğretmenin verdiği dönütlerle yazının içerik ve biçimsel olarak doğru şekillenmesinin sağlanmasıdır.

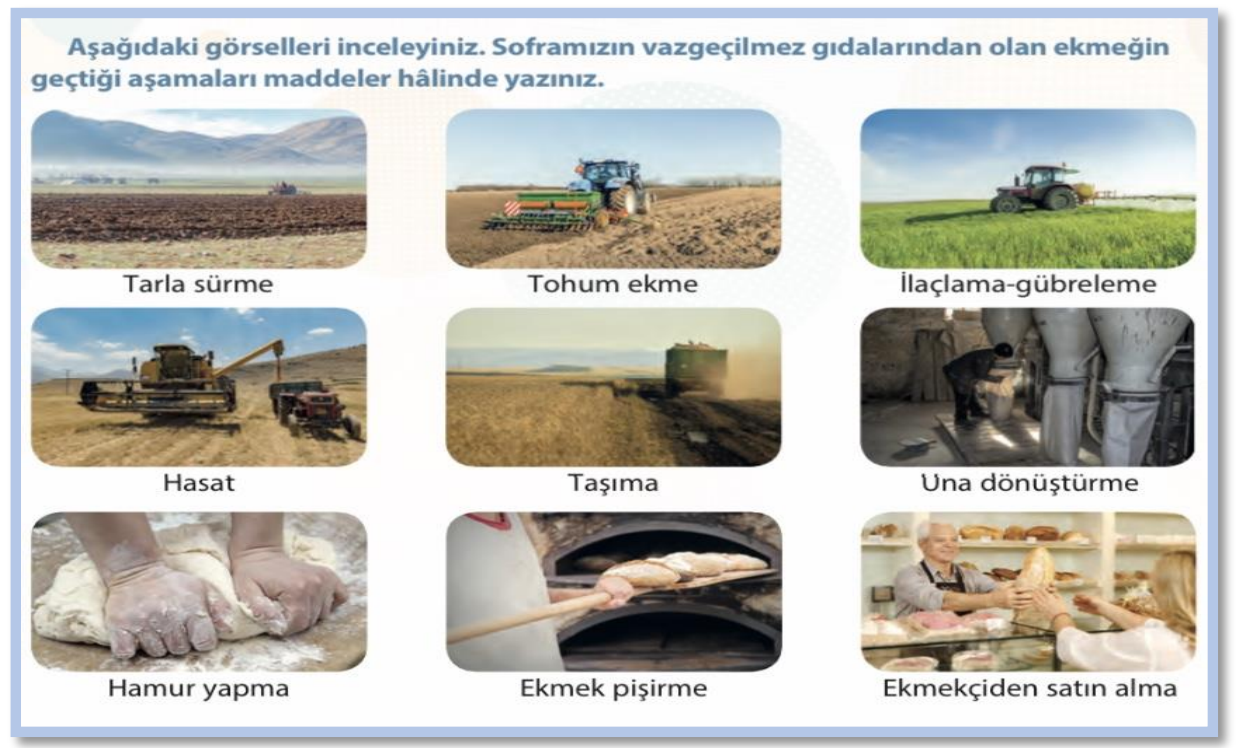

Resim 11. "Birey ve Toplum/ipek Kelebeği/7. Etkinlik" Örneği (Ataşçi, 2019, s. 224) 
Resim 11'de Birey ve Toplum teması "ipek Kelebeği” metni 7. etkinliğinde öğrencilerden ekmeğin yapılış aşamalarını maddeler halinde yazmaları istenmektedir. Yazdıklarını gözden geçirip yazım ya da noktalama hataları varsa düzeltmeleri ve daha sonra metni arkadaşlarına okumaları istenmektedir. Ders kitabında yer alan bu etkinlikle, yazma işleminin son aşaması olan yayınlama aşamasında öğrenciler, ortaya koydukları metinleri arkadaşlarıyla ya da aileleriyle paylaşmaktadır. Bu noktada öğretmen, bu durumu öğrenciler için anlamlı hale getirerek yazmanın etkili bir paylaşma aracı olduğunu belirtip onları güdüleyebilmelidir. Yayınlama aşamasının sağlıklı geçmesi için öğretmenin önceki süreçlerde öğrencinin yazılarını gözden geçirmesi ve öğrenciye rehber olması gerekmektedir. Böylece öğrenci yayınlama aşamasına geldiğinde gönüllü bir şekilde yazısını paylaşmak isteyecek ve oluşturduğu ürünü sergileyecektir.

Süreç Temelli Yazma temasının son alt teması "Aşamalara Dikkat Çekme"de yer alan etkinliklere $(\mathrm{f}=2)$ şu şekilde bir örnek verilebilir:

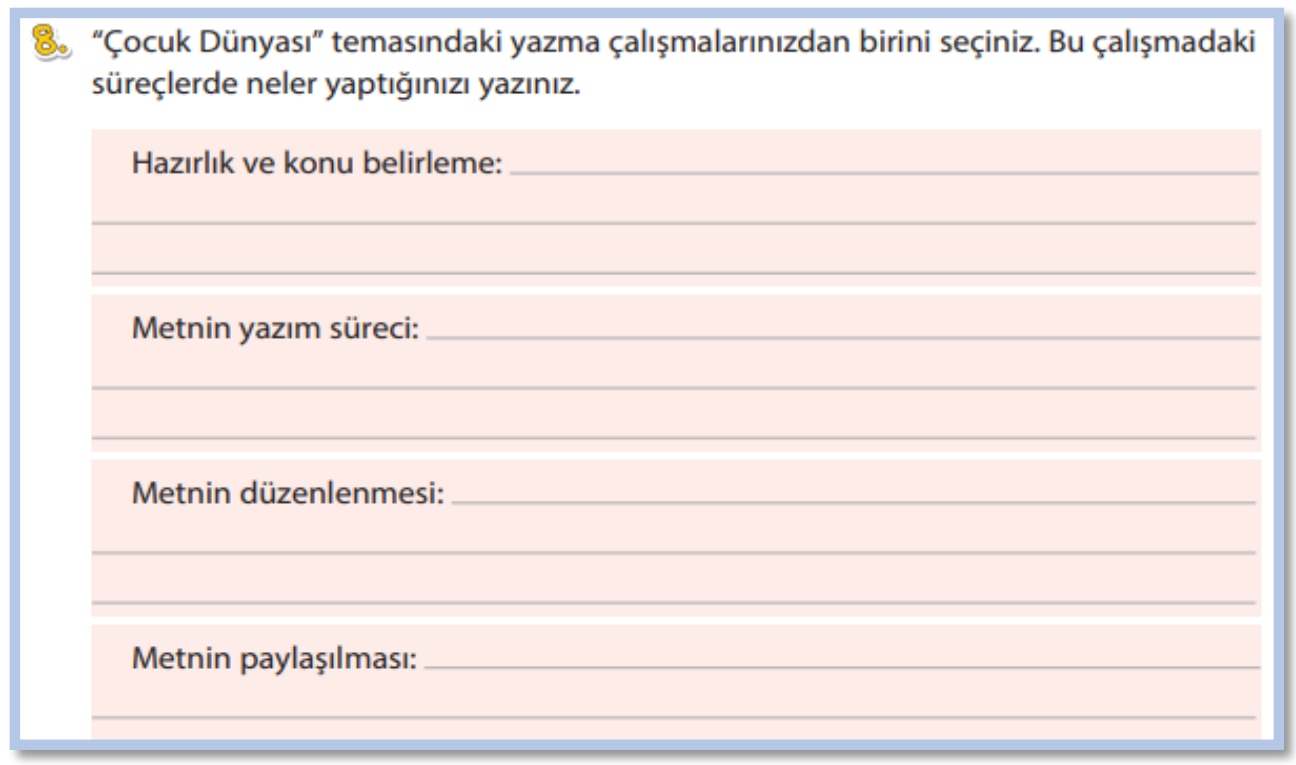

Resim 12. "Çocuk Dünyası/Değerlendirme/8. Etkinlik" Örneği (Ataşçi, 2019, s. 44)

Resim 12'deki Çocuk Dünyası teması değerlendirme bölümünün 8. etkinliğinde öğrencilerden bir metnin oluşum sürecindeki aşamalarda neler yaptıklarını yazmaları istenmektedir. Etkinlikte de görüldüğü üzere yazma süreci belirli aşamalardan oluşmaktadır ve bu süreç öğrencilerin düşüncelerini planlayabilme, düzenleyebilme ve değerlendirebilme yeteneği kazandırmaktadır. Etkinlikler sırasında aşamaların öğretmenler tarafından oluşturulup uygulanması tema sonu değerlendirme sorularında öğrencinin bilgilerini pekiştirmesini sağlayabilir.

\section{Metin Türüyle ilişkilendirilemeyen Etkinlikler Temasına ilişkin Bulgular}

Tablo 3'te görüldüğü gibi "Metin Türüyle Illişkilendirilemeyen Etkinlikler" teması ( $f=16$ ) altında Türkçe Dersi Öğretim Programı'nda belirtilen şiir, bilgi verici metin ve hikâye edici metin türlerine ilişkin bir yönergenin yer almadığı, T.4.4.1 "Şiir yazar", T.4.4.3 "Hikâye edici metin yazar." ve T.4.4.4 "Bilgilendirici metin yazar." kazanımları altında verilemeyen, öğrenciye metin türü seçimiyle ilgili bilgi verilmeyen yazma etkinlikleri yer almaktadır. Türkçe Dersi Öğretim Programı'nda metin türlerine ilişkin sınıflara göre dağılımlar söz konusuyken buna yazma etkinliklerinde yer vermemek öğrencinin yazmasını zorlaştırabilir. Bu süreçte öğretmenler öğrencileri yönlendirmeli ve öğrencilerin hangi metin türünde, nasıl bir yol izleyeceği belirtilmelidir. 
Tablo 3.

IIlkokul 4. Sınıf Türkçe Ders kitabındaki Yazma Etkinliklerinde Yer Alan "Metin Türüyle ilişkilendirilemeyen Etkinlikler" Temasına ilişskin Bulgular

\begin{tabular}{llc}
\hline TEMA & ETKiNLiK NUMARASI & $f$ \\
\hline & Çocuk Dünyası/Kuş Çocuk/8, & 16 \\
& Çocuk Dünyası/Rafadan Tayfa ile Sokak Oyunları/6, \\
& Milli Mücadele ve Atatürk/Müstecip Onbaşı/8, \\
& Milli Mücadele ve Atatürk/Başkomutan Mustafa \\
& Kemal/7, \\
& Milli Mücadele ve Atatürk/Beni de Tanık Olarak \\
& Göster/7b, \\
& Milli Mücadele ve Atatürk/Atatürk/5, \\
& Erdemler/Leylek ve Tilki/6b, \\
& Milli Kültürümüz/Hepsi Haklı/7, \\
& Milli Kültürümüz/Tarihi Eserleri ve Mutfağılyla Ünlü \\
& Kentimiz Hatay/6, \\
& Doğa ve Evren/Küçük müyüz, Büyük mü?8, \\
Detin türüyle ilişkilendirilemeyen ve Evren/Ateş Böceği/5, \\
etkinlikler & Sanat/Sinema/7, \\
& Birey ve Toplum/Eskisiyle Para Babası/7, \\
& Birey ve Toplum/Ah Heidi Neredesin?/7, \\
& Birey ve Toplum/Sözcükler/6 \\
& Bilim ve Teknoloji/Beyin Ne iş Yapar?/7 \\
\hline
\end{tabular}

Tablo 3'te "Metin Türüyle illişkilendirilemeyen Etkinlikler" temasına ilişkin verilen etkinlik numaralarından şöyle örnekler verilebilir:

Mustafa ve Kemal olmak üzere iki ismi olan Atatürk kendi imzasında Kemal isminin baş harfini kullanmıştır. Eğer sizin de iki isminiz varsa bir tanesinin baş harfini imzanızda kullanmakta sakınca olmayacaktır. İmzanızı oluştururken birçok kez aynı şekilde yazmaya özen gösteriniz. Atatürk'e karşı duygu ve düşüncelerinizi dile getirdiğiniz kısa bir metin yazınız. Sayfanın sağ alt kısmında yer alan yere imzanızı öğretmeninizden de gerekli desteği alarak atınız.

Resim 13. “Milli Mücadele ve Atatürk/Atatürk/5. Etkinlik" Örneği (Ataşçi, 2019, s. 70)

Resim 13'te Milli Mücadele ve Atatürk teması “Atatürk" metni 5. etkinliğinde görüldüğü gibi öğrencilerden Atatürk'e karşı duygu ve düşüncelerini dile getirebilecekleri bir metin yazmaları istenmiştir. Bu etkinlikte öğrencilerden bilgilendirici ya da hikâye edici türde bir metin yazmaları açıkça belirtilmemektedir. Bu aşamada öğretmenin yönlendirmesiyle öğrenciler, bir metnin yazım aşamalarını yerine getirerek herhangi türde bir metin ortaya koyabilirler. 
Așağıdaki karikatürü inceleyiniz. Karikatür hakkındaki düșüncelerinizi yazınız. Yazınızı bitirdikten sonra tekrar okuyarak varsa yazım ve noktalama yanlışlarınızı düzeltiniz.

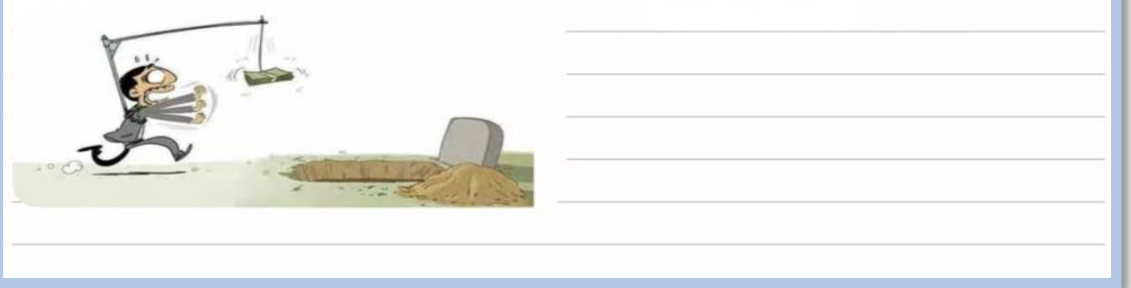

Resim 14. "Birey ve Toplum/Eskiciyle Para Babası/7. Etkinlik" Örneği (Ataşçi, 2019, s. 209)

Resim 14'te Birey ve Toplum Teması "Eskiciyle Para Babası” metni 7. etkinliğinde verilen örnekte bir karikatürden yola çıkarak öğrencilerden düşüncelerini yazmaları istenmektedir. Kitapta yer alan bu örnekte de belirli bir metin türünden bahsedilmemektedir. Öğrencilerin fikirlerini serbest bir metin halinde ortaya koyduktan sonra gerekli düzeltmeleri yapmaları istenmiştir. Etkinlik, öğrencilerden duygu ve düşüncelerini anlatan bir yazı yazmalarını isteme yönündedir. Ancak bu düşüncenin hangi metin türüne ait olması gerektiği konusunda bir yönlendirme söz konusu değildir.

Milli Kültürümüz teması "Hepsi Hakı” metni 7. etkinliği "Çevrenizde Nasrettin Hoca'ya benzettiğiniz kişiler var mıdır? Böyle bir kişinin özelliklerini aşağıya yazınız. Yazınızda bu kişinin kişilik özelliklerini, olaylara verdiği tepkileri örneklerle açıklayınız." ve "Tarihî Eserleri Ve Mutfağıyla Ünlü Kentimiz Hatay" metni 6. etkinliği "Yaşadığınız veya gezip gördügünüz yerlerden birini anlatan bir yazı yazınız." örneklerinde de görüldüğü gibi öğrenciler bu konuya yönelik şiir, hikâye edici metin ya da bilgilendirici metin yazabilir. Bu tür etkinliklerde öğretmen rehberliğinde bir metin türü belirlenerek aşamalar halinde bir yazım süreci meydana getirilmelidir. Öğretmen rehberliğinde metin türü seçmek, metnin içeriğini oluşturmak anlamında da önem taşımaktadır. Anı, günlük, kartpostal, özlü sözler gibi içeriklerin yazılacağı bilgilendirici metin türleri gibi fabl, hikâye, masal vb. gibi hikâye edici metin türleri öğrencilere tanıtılıp öğrencilerin bunlara yönelik yazılarını şekillendirmeleri istenebilir. Böylelikle öğrenciler metin türleriyle beraber anlatım tarzını, hedef kitlesini, konunun içeriğini daha rahat oluşturabilir.

Bunun yanı sıra Sanat teması "Sinema" metni 7. etkinliğinde "Bir blog yazarı olduğunuzu düşününüz. Bugün yaşadıklarınızı aşağıdaki yazma alanına yazınız. Yazınızı yazdıktan sonra gözden geçirerek noktalama ve yazım yanlışlarınız varsa bunları düzeltiniz. Isterseniz yazdıklarınızı arkadaşlarınıza okuyunuz." örneğiyle öğrencilerden bir blog yazarı gibi bir yazı yazmaları istenmiştir. Ancak Türkçe Dersi Öğretim Programı'nda sınıf düzeylerine göre metin türlerinin dağılımında (MEB, 2019 , s. 16) bilgilendirici metin türündeki blog, 6. sınıftan sonra verilmektedir. Metin örneğini görmediği bir türün öğrencilerden etkinlik sırasında istenmesi öğrencinin yazmasını zorlaştıracaktır. Bu bağlamda verilen etkinliklerin öğrenci düzeyine uygun metin türü olması önemlidir.

\section{Tartışma ve Sonuç}

Türkçe ders kitabındaki yazma etkinlikleri kazanım, süreç temelli yazma ve metin türüyle ilişkilendirilemeyen etkinlikler olarak 3 temada incelenmiştir. Türkçe ders kitabındaki yazma etkinlikleri yazma kazanımları doğrultusunda incelendiğinde en çok "T.4.4.10. Büyük harfleri ve noktalama işaretlerini uygun yerlerde kullanır." kazanımının etkinliklerde vurgulandığı görülmüştür. Bu araştırma sonucundan farklı olarak Demir Atalay (2015) noktalamaya ilişkin kazanımların öğrencilere kazandırılması yönünden yetersiz olduğunu ortaya koymuştur. Türkçe Dersi Öğretim Programı'nda yer alan 4. sınıf düzeyindeki 22 kazanımdan "T.4.4.17. Sayıları doğru yazar.", "T.4.4.20. Harflerin yapısal özelliklerine uygun metin yazar.", "T.4.4.21. Yazma stratejilerini uygular." ve "T.4.4.22. Pekiştirmeli sözcükleri doğru yazar." kazanımları olmak üzere 4 kazanımın etkinliklerde yer almadığı görülmüştür. Çerçi'nin (2016) yaptığı araştırmada etkinlikler amaca göre gruplandırıldığında etkinliklerin büyük bir kısmının $(\% 92,10)$ bir kazanımı pekiştirmek amacıyla hazırlandığı görülmüştür. Bu çalışmada da benzer 
bir sonuç söz konusundur. Bazı kazanımlar eksik olsa da her etkinlikte en az bir kazanımın vurgulandığı görülmektedir.

Türkçe ders kitabındaki etkinliklerin süreç temelli yazmaya uygunluğu incelendiğinde etkinliklerdeki yönergelerin çoğunun öğrencilerin bir yazma ürünü çıkarmasına yönelik olduğu, süreç temelli yazmaya ilişkin olarak çoğunlukla düzeltme ve yayınlama aşamasına yönelik öğrencilere yönergeler verildiği görülmektedir. Konu seçimi ve konunun tasarlanmasına dair bazı etkinliklerde yönlendirmeler söz konusu olduğu ortaya çıkmıştır. Bu çalışmada olduğu gibi Karacaoğlu, Dağ ve Uzun (2021) da yazma etkinliklerinin daha çok ürün odaklı ve öğretmen yönlendirmesiyle ilerleyecek şekilde planlandığını vurgulamaktadır. Bunun yanı sıra Türkçe ders kitabındaki bazı etkinliklerde giriş, gelişme, sonuç bölümlerinin açıklandığı yönergeler verilmiştir. Ancak bu sürecin detaylandırılması ve içeriğinin oluşturulması öğretmen rehberliğine bırakılmıştır. Etkinlikler incelendiğinde özellikle yazma sırasında öğrencilerin sürece yönelik yönlendirmesi eksik kalmaktadır. Benzer bir sonuç Demir Atalay'ın (2015) çalışmasında ders kitabında, yazma süreçleri açısından yazma öncesi, sırası ve sonrası etkinliklerinin yetersiz olduğu yönünde ortaya konulmuştur.

Türkçe ders kitabındaki her metin altında yazma etkinliklerine yer verilmiştir. Çevik ve Güneş (2017) de araştırmalarında ders kitaplarında "Yazma" becerisine yönelik çalışmalara bolca yer verildiğini belirtmektedir. Bunun yanı sıra etkinliklerde yönlendirme, metin üretmeye dair çalışmalar olmadığı sonucuna ulaşılmaktadır. Bu araştırmada da ders kitabının yazma etkinliklerinde öğrencilerden bir metin oluşturmaları, bir yazı yazmaları istendiği görülmüş ancak metnin türüne yönelik bir yönlendirmenin oldukça az olduğu ortaya konulmuştur. Bu bağlamda metin türü seçiminde öğretmenlerin öğrenciyi yönlendirmesi önem kazanmaktadır.

Araştırmada elde edilen sonuçlar doğrultusunda şu öneriler sunulabilir:

- Yazma etkinlikleri kazanımlar, süreç temelli yazma ve öğrencilere farklı metin türlerinde metin yazmalarını sağlamaya yönelik olarak tekrar gözden geçirilebilir.

- Farklı yayınevleri ve sınıf seviyesindeki ders kitapları incelenerek yazma etkinliklerinin durumu ortaya konulabilir.

- Örnek etkinlikler tasarlanarak öğretmenlere yazma eğitimi konusunda kılavuz kitaplar oluşturulabilir.

\section{Araştırma ve Yayın Etiği}

Bu çalışmada "Yükseköğretim Kurumları Bilimsel Araştırma ve Yayın Etiği Yönergesi" kapsamında uyulması belirtilen tüm kurallara uyulmuştur. Yönergenin ikinci bölümü olan "Bilimsel Araştırma ve Yayın Etiğine Aykırı Eylemler" başlığı altında belirtilen eylemlerden hiçbiri gerçekleştirilmemiştir.

\section{Yazarların Katkı Oranı}

1. yazar $\% 50,2$. yazar $\% 50$ oranlarında olmak üzere tüm yazarlar bu çalışmaya eşit katkı sağlamışlardır.

\section{Çıkar Çatışması}

Çıkar çatışması teşkil edebilecek bir durum yoktur.

\section{Kaynaklar}

Ataşçi, A. (2019). ilkokul Türkçe 4 ders kitabı. Ankara: Koza Yayın.

Bowen, G. A. (2009). Document analysis as a qualitative research method. Qualitative Research Journal, 9(2), 27-40. DOI: 10.3316/QRJ0902027.

Çiçek, M. ve Alcellat, N. (2014). İlköğretim Türkçe dersi kitaplarındaki Türkçe yanlışları ve eksiklikler üzerine bir inceleme. Ana Dili Eğitimi Dergisi, 2(4), 120-134.

Çerçi, A. (2016). 6. sınıf Türkçe dersi öğrenci çalışma kitabının etkinliği oluşturan unsurlar bakımından değerlendirilmesi. Uluslararası Türkçe Edebiyat Kültür Eğitim Dergisi, 5(4), 1984-1998.

Çevik, A. ve Güneş, F. (2017). Türkçe ders kitaplarındaki etkinliklerin incelenmesi. Ana Dili Eğitimi Dergisi, 5(2), 272-286. DOI: 10.16916/aded.288848. 
Demir Atalay, T. (2015). Yazma becerisi açısından örnek bir kitap incelemesi. Aü Türkiyat Araştırmaları Enstitüsü Dergisi (TAED), 54, 727-777.

Güneş, F. (2014). Türkçe öğretimi yaklaşımlar ve modeller (3. Baskı). Ankara: Pegem Akademi Yayıncılık. Kasa Ayten, B. (2018). Yazma eğitimi. S. M. Taşkaya ve R. Karadağ (Ed), Türkçe öğretimi içinde (s. 103124). İstanbul: Lisans Yayıncılık.

Karacaoğlu, M.Ö., Dağ, M. ve Uzun, O. (2021). Türkçe ders kitaplarındaki yazma etkinliklerinin incelenmesi. IBAD Sosyal Bilimler Dergisi, 6(10), 96-126. DOI: 10.21733/ibad.852233.

Karadağ, R. (2016). Yazma eğitimi. F. Susar Kırmızı (Ed), ilk ve ortaokullarda Türkçe öğretimi içinde (s. 163-210). Ankara: Anı Yayıncılık.

Kavcar, C. (2009). Yazılı anlatım. Ş. D. Belet (Ed.), Türkçe sözlü ve yazılı anlatım içinde (s. 107-125). Eskişehir: Anadolu Üniversitesi.

MEB (2015). Türkçe dersi öğretim programı (1-8. Sınıflar). Ankara: Millî Eğitim Bakanlığı.

MEB (2019). Türkçe dersi öğretim programı (ilkokul ve ortaokul 1, 2, 3, 4, 5, 6, 7 ve 8. sınıflar). Ankara: Millî Eğitim Bakanlığı.

Miles, M. B. ve Huberman, A. M. (1994). Qualitative data analysis: An expanded sourcebook. (2. Edition). California: SAGE Publications.

Murray, D. (1972). Teach writing as process, not product. T. Newkirk \& L. C. Newkirk (Eds), Lessons from American's gretest writing teacher (pp. 2-5). Portsmouth NH: Boynton/Cook Publishers.

Oral, G. (2012). Yine yazı yazıyoruz-okulda/işyerinde/evde kullanılabilecek yaratıcı yazı etkinlikleri ve kuramsal temelleri (4. Baskı). Ankara: Pegem Akademi Yayıncılık.

Özdemir, B. (2014) Analitik değerlendirme ve yazma modelinin Türkçe öğretmeni adaylarının yazma becerilerine ve yazma tutumlarına etkisi (Yayımlanmamış Doktora Tezi). Gazi Üniversitesi Eğitim Bilimleri Enstitüsü, Ankara.

Temizkan, M. (2007). Türkçe öğretmenlerinin yazılı anlatım etkinliği çerçevesinde yaptıkları uygulamaların değerlendirilmesi. Milli Eğitim, 36(174), 135-154.

Temizkan, M. (2014). Yaratıcı yazma süreci. Ankara: Pegem Akademi Yayıncılık.

Tompkins, G. E. (2002). Language arts content and teaching strategies (5. Editon). Upper Saddle River New Jersey: Pearson Education.

Wach, E. (2013). Learning about qualitative document analysis. https://opendocs.ids.ac.uk/opendocs/bitstream/handle/20.500.12413/2989/PP\%20InBrief\% 2013\%20QDA\%20FINAL2.pdf?sequence=4 adresinden 27.01.2021 tarihinde edinilmiştir.

Yıldırım, A. ve Şimşek, H. (2018). Sosyal bilimlerde nitel araştırma yöntemleri (11. Baskı). Ankara: Seçkin Yayıncılık.

\section{Introduction}

\section{Extended Abstract}

Primary school is the first education level through which language skills are acquired formally. Individuals acquire all of the language skills in their family and environment prior to formal education. The acquisition of narrative and expression skills such as speaking and writing, besides the comprehension skills such as listening and reading, is central in this formal process and maintained a lifetime. The individual's comfort in their education life after primary school requires a completed language skill acquisition process in primary school (Özdemir, 2014). Thus, priority is given to language skill acquisition in primary school, especially in Turkish lessons.

One of the most difficult skills to gain is writing skills that enable individuals to express themselves in a written form. Writing is transcribing mentally structured information with certain symbols through certain rules (Güneş, 2014; Karadağ, 2016). The Turkish Course Curriculum implies that students develop their writing skills through expressing their imaginations, designs, feelings and thoughts by focusing on a subject and considering the grammatical rules and turn it into practice (MEB, 2015). Writing education aims to enable individuals to express their feelings and thoughts with accurate expressions by their genuine writing styles through writing. It is not easy to acquire writing skills without training. 
Writing on ordinary topics that do not encourage creative thinking or new and original ideas in writing activities with traditional writing education methods bore students and they become reluctant after a while. Therefore, it is observed that students' self-confidence decreases and they have difficulty in self-expression in writing activities not guided by the teacher. So, writing activities end after a while (Temizkan, 2014). The transition from a product-based approach to a process-based approach enables individuals to develop writing skills both in form and content under teacher supervision. This approach conceptualizes writing as the discovery, renewal and change of thought and language. Therefore, the teacher-student relationship is considered similar to the interaction between a master and an apprentice. Thus, teachers can better understand and guide the students (Oral, 2012,).

Writing under the teacher guidance by considering certain stages provides writing skill improvements, a positive attitude and motivation towards writing. The more authenticity in the writing activities in Turkish course lessons, the more remarkable it will be for the students. Moreover, students' awareness of writing skills shall improve the process dimension, and the teacher guidance in the writing process enables the student to answer the question of "How can I write better?". Particularly, the fact that the activities in Turkish course textbooks improve the writing skills is of substantial help to teachers in this process. Therefore, it is vital to examine the writing activities in Turkish course textbooks to relieve writing education from the ordinariness and improve it. This study aims to examine the writing activities in the $4^{\text {th }}$-grade Turkish course textbook and reveal the properties of these activities in terms of writing skills.

\section{Methods}

A qualitative research approach was followed, and the document analysis method was used in this study. Wach (2013) defined document analysis as "a research method used to analyze the written document content meticulously and systematically". The document review method, including a detailed research, was conducted on the analyzed documents. This study utilized the document analysis method to analyze the activities in Turkish course textbooks regarding writing skills.

A $4^{\text {th }}$-grade Turkish course textbook approved by the Ministry of National Education, used in primary schools during the 2020-2021 academic year, was selected through criterion sampling. The activities in the selected book were impartially examined in terms of writing.

The data regarding the activities in the $4^{\text {th }}$-grade Turkish course textbook for primary schools were analyzed by descriptive analysis technique. Descriptive analysis was applied to evaluate whether the topics are adequately covered in the literature. This technique requires information interpretations based on the determined themes and frequent direct quotations to present the interviewee opinions more effectively (Yıldırım \& Şimşek, 2018). This method was applied due to the lack of adequate information in contemporary scholarship on the subject and to examine the writing skill activities in the Turkish course textbook for more information. The document on the $4^{\text {th }}$-grade writing objectives in the Turkish Course Teaching Program and the data was analyzed.

\section{Result and Discussion}

Writing activities in the Turkish Textbook were examined under 3 themes as outcome, processbased writing, and activities not focusing on the text type.

It was observed that the writing activities in the Turkish Course Textbook mostly focuses on the "T.4.4.10. Using capitalization and punctuation accurately" outcome. The study results contradict Demir Atalay's (2015) attempt revealed that the punctuation outcome targets are inadequately realized in students. It was discovered that 4 outcomes, "T.4.4.17. Writing the numbers correctly.", "T.4.4.20. Writing texts suitable with the structural features of letters.", "T.4.4.21. Applying writing strategies." and "T.4.4.22. Writing intensifier words accurately.", were omitted in the Turkish Course Teaching Program activities. Çerçi (2016) grouped the activities by their purpose and revealed that most of the activities (92.10\%) were prepared to reinforce an acquisition. This study also generated similar results. Although some outcomes are neglected, it was observed that at least one acquisition is emphasized in each activity. 
The appropriateness of the activities in the Turkish Course Textbook to process-based writing was evaluated. It was found that the majority of the instructions in the activities are for composing a writing product as the students are mostly instructed at the process-based writing, editing and publishing stages. It has been revealed that there is some guidance in a part of the activities regarding the topic selection. Karacaoğlu, Dağ, and Uzun (2021) emphasized that writing activities are planned in a more product-oriented way and progresses with teacher guidance which coincides with the study. Besides, some instructions, with introduction, body and conclusion sections, are provided in the activities. However, the elaboration and content regarding this process should only function under the teacher guidance. The activities indicate that students are inadequately supervised, especially during writing. Similar results were found in Demir Atalay's (2015) study on a textbook that the activities before, during and after writing were insufficient regarding writing processes.

Writing activities are included under each text in the Turkish Course Textbook. Çevik and Güneş (2017) also argued that there are several studies on "Writing" skills in textbooks. Furthermore, it is concluded that there is little scholarship on guidance and text production in writing activities. This study revealed that students were asked to compose a text and write an essay in the textbook's writing activities as there was limited guidance for the text type. 